\title{
ANALISIS KEMAMPUAN BEPIKIR KRITIS MATEMATIK SISWA SMP DI KABUPATEN BANDUNG BARAT
}

\author{
Nina Lestari ${ }^{1}$, Riki Andriansyah ${ }^{2}$, Dinar Nur Azizah ${ }^{3}$, Sopian Lukman ${ }^{4}$, Wahyu Hidayat ${ }^{5}$ \\ 1,2,3,4,5 Program Studi Pendidikan Matematika IKIP Siliwangi, J1. Terusan Jenderal Sudirman \\ ${ }^{1}$ lestarisnsd@gmail.com, ${ }^{2}$ rikiandriansyah.ra@gmail.com, ${ }^{3}$ dinarazizah212@gmail.com, \\ ${ }^{4}$ sopianlukman14@gmail.com, ${ }^{5}$ wahyu@ikipsiliwangi.ac.id
}

\begin{abstract}
The ability to think critically is one of the highest levels of ability. Developing critical thinking skills in students is still considered important to be improved in schools so that students are able and accustomed to facing various problems around it. This study aims to analyze the critical thinking skills of junior high school students who are in excellent classes and regular classes. This research was conducted in Bandung Barat. In this study students are given a test in the form of questions with critical thinking skills, the problem is used to compare between the superior class and ordinary class. Assessment of the problem using several factors of critical ability include 1) students can not understand the problem correctly, 2) students rush in doing the problem, 3) the students cannot choose the problem-solving strategy correctly and 4) the students work on the problem systematically. Then the matter of critical thinking skills of mathematics is analyzed using quasi-experimental research method to analyze students' critical thinking ability that influence learning result. This study shows the differences in critical thinking ability of junior high school students who are in excellent class and ordinary class. This study shows that superior classes are better in mathematical critical thinking ability than a regular class. The results of this study can add knowledge about critical thinking mathematics junior high school students who are in the class and ordinary class and used to facilitate for educational practitioners in the development of critical mathematical thinking skills.
\end{abstract}

Keywords: Mathematical Critical Thinking, Excellent Class.

\begin{abstract}
Abstrak
Kemampuan berpikir kritis adalah salah satu kemampauan tingkat tinggi. Mengembangkan kemampuan berpikir kritis pada siswa masih dianggap penting untuk ditingkatkan di sekolah agar siswa mampu dan terbiasa menghadapi berbagai permasalahan di sekitarnya. Penelitian ini bertujuan untuk menganalisis kemampuan berpikir kritis matematik siswa SMP yang berada di kelas unggulan dan kelas biasa. Penelitian ini dilakukan di salah satu kabupaten Bandug Barat. Dalam penelitian ini siswa diberi tes dalam bentuk soal dengan kemampuan berpikir kritis, soal tersebut digunakan untuk membandingkan antara kelas unggulan dan kelas biasa. Penilaian soal tersebut menggunakan beberapa faktor kemampuan kritis diantaranya 1) siswa tidak dapat memahami soal dengan benar, 2) siswa terburuburu dalam mengerjakan soal, 3) siswa tidak dapat memilih strategi pemecahan masalah dengan benar dan 4) siswa mengerjaan soal dengan sistematis. Kemudian soal kemampuan berpikir kritis matematik tersebut dianalisis menggunakan metode penelitian quasi eksperimen untuk menganalisis kemampuan berpikir kritis matematik siswa yang mempengaruhi hasil belajar. Penelitian ini menunjukan perbedaan kemampuan berpikir kritis siswa SMP yang berada di kelas unggulan dan kelas biasa. Penelitian ini menunjukan bahwa kelas unggulan lebih baik dalam kemampuan berpikir kritis matematik dibandingkan kelas biasa. Hasil penelitian ini dapat menambah pengetahuan tentang berpikir kritis matematik siswa SMP yang berada dikelas unggulan dan kelas biasa dan berguna untuk memfasilitasi bagi para praktisi pendidikan dalam pengembanagan keterampilan berpikir kritis matematik.
\end{abstract}

Kata Kunci: Berpikir Kritis Matematis, Kelas Unggulan. 
How to cite: Lestari, N., Andriansyah, R., Azizah, D. N., Lukman, S., \& Hidayat, W. (2018). Pengaruh Self Confidence Siswa SMP terhadap Kemampuan Berpikir Kreatif Matematis Siswa. JPMI - Jurnal Pembelajaran Matematika Inovatif, 1 (4), 667-672.

\section{PENDAHULUAN}

Matematika adalah ilmu yang secara jelas mengandalkan proses berpikir. Sehingga tujuan utama dari mengajarkan matematika tidak lain untuk membiasakan siswa mampu berpikir logis, kritis dan sistematis. Syahbana (2012) mengatakan bahwa berpikir kritis sangat diperlukan bagi kehidupan, supaya mereka dapat memilah informasi, memilih pantas atau tidaknya suatu kebutuhan, mempertanyakan kebenaran yang biasanya ditutupi dengan kebohongan, dan segala sesuatu bisa saja membahayakan kehidupan mereka. Namun berpikir kritis ini masih belum dibiasakan. Sesuai dengan yang dikatakan oleh Syahbana (2012) yang mengatakan bahwa guru lebih sering meminta siswa untuk menjelaskan kembali, mendefinisikan, menggambarkan, menguraikan, dan mendaftar daripada menganalisis, membuat kesimpulan, menghubungkan, mensintesakan, mengkritik, menciptakan, mengevalusi, memikirkan dan memikirkan ulang. Sehingga, hal itu mengakibatkan siswa yang lulus berpikir secara kurang mendalami, bukan siswa-siswa yang mampu berpikir secara mendalam.

Secara umum berpikir kritis adalah menganalisis ide atau gagasan kearah yang lebih rinci atau spesifik dan berpikir kritis itu sendiri bagian dari tujuan diberikannya matematika dalam dunia pendidikan. Mengajarkan dan mengembangkan kemampuan berpikir kritis masih dianggap sebagai sesuatu yang penting untuk ditingkatkan di sekolah agar siswa mampu dan terbiasa menghadapi berbagai permasalahan di sekitarnya. Oleh sebab itu, guru tidak boleh mengabaikan pengembangan kemampuan berpikir kritis siswa (Hidayat, 2011; 2012; Sumarmo, Hidayat, Zukarnaen, Hamidah, \& Sariningsih, 2012; Tresnawati, Hidayat, \& Rohaeti, 2017). Ikhsan, \& Rizal (2014) mengatakan bahwa Orang yang berpikir kritis matematis akan cenderung memiliki sikap yang positif terhadap matematika, sehingga akan berusaha menalar dan mencari strategi penyelesaian masalah matematika.

Kemampuan bepikir kritis dapat dilaksanakan melalui proses pembelajaran dimana siswa terlibat aktif secara langsung, mengajukan permasalahan yang sulit serta siswa menyimpulkan kesimpulan dari permasalahan yang mereka hadapi (Rasiman, 2012). Hasil penelitian oleh Hendyawan, Yusuf, Wachar, Ciregar, \& Dwiyani (2017) menyatakan bahwa siswa yang memiliki kemampuan rendah terkadang menggunakan informasi dengan menggunakan katakata, tidak dengan menggunakan simbol maupun menuliskan penyelesaian secara sistematis. Saat melakukan wawancara, siswa merasa kesulitan ketika harus menuliskan strategi yang digunakan untuk memecahkan masalah terkadang melewatkan tahap tersebut dan langsung mengerjakan soal untuk mencapai tujuan akhir. Siswa yang mempunyai kemampuan awal tinggi tidak dapat mencapai tahap maksimum dalam berpikir kritis. Siswa ini tidak dapat menguasai indicator yaitu Menentukan persamaan dan perbedaan antara yang diberikan masalah dengan masalah lainnya serta tidak dapat menganalisis persamaan dan perbedaan masalah yang baru diberikan sdengan masalah masalah lainnya yang pernah diselesaikan.

Berdasarkan penelitian diatas, kemampuan berpikir kritis matematik siswa dengan kemampuan kritis matematik rendah kesulitan menyelesaikan masalah secara sistematis. Dan untuk subjek dengan kemampuan matematik tinggi kesulitan dalam mencapai tahap maksimum dalam berpikir kritis matematik. 


\section{METODE}

Metode Metode penelitian yang digunakan adalah penelitian quasi eksperimen untuk menganalisis kemampuan berpikir kritis matematik siswa yang mempengaruhi hasil belajar. Adapun desain penelitian yang dipakai adalah desain kelompok kontrol nonekuivalen (Ruseffendi, 2010).

Populasi dalam penelitian ini adalah siswa dari salah satu SMP di Kabupaten Bandung Barat sebanyak 40 siswa. Dipilih dua kelas dari populasi tersebut yaitu kelas unggulan dan kelas biasa. Pada SMP ini ada kelas yang menjadi unggulan yaitu kelas VII A dengan 20 siswa dan juga beberapa kelas biasa. Dan untuk kelas biasa dipilih kelas VII B dengan 20 siswa. Penelitian ini dilaksanakan pada tanggal 09 Mei 2018. Dalam penelitian ini dilakukan uji tes dengan materi segitiga dan segiempat kelas VII. Siswa diberikan 5 butir soal dengan kemampuan berpikir kritis matematik. Setiap soal memiliki skor atau nilai adalah 4. Dengan demikian nilai tertinggi yang dapat didapatkan siswa adalah 20 .

Teknik pengumpulan data yang digunakan dalam penelitian ini adalah tes. Tes ini dilakukan untuk mengukur kemampuan berpikir kritis matematik. Hasil tes kemampuan berpikir kritis matematik kemudian dianalisis untuk menguji kebenaran hipotesis penelitian. Analisis data tersebut dilakukan dengan menggunakan uji normalitas dan uji perbedaan rata-rata. Uji normalitas digunakan untuk menentukan bahwa data yang telah dikumpulkan berdistribusi normal atau tidak berdistribusi normal. Uji perbedaan rata-rata digunakan menguji kemampuan perbedaan berpikir kritis matematik kelas mana yang lebih baik.

\section{HASIL DAN PEMBAHASAN}

\section{Hasil}

Setelah menguji tes pada siswa SMP dapat dilihat hasil tes kemampuan berpikir matematik siswa pada Tabel 1.

Tabel 1. Hasil Tes Kemampuan Berpikir Kritis Matematik

\begin{tabular}{lllll}
\hline \multirow{2}{*}{ Kelompok } & \multicolumn{2}{l}{ Hasil Tes Kemampuan Berpikir Kritis Matematik } & \\
& Jumlah & Rata-rata & Nilai Tertinggi & Nilai Terendah \\
\hline Kelas Biasa & 20 & 11.90 & 16 & 8 \\
Kelas Unggulan & 20 & 15.50 & 20 & 10 \\
\hline
\end{tabular}

Tabel 1. Menunjukan bahwa rata-rata nilai untuk kelas biasa adalah 11.90 dan untuk kelas unggulan yaitu 15.50. Dapat dilihat pula nilai tertinggi dan terendah yang didapatkan siswa. Kelas Biasa mendapat nilai tertinggi 16 dan nilai terendah 8. Kelas unggulan mendapat nilai tertinggi 20 dan nilai terendah 10.

\section{Pembahasan}

Berdasarkan hasil tes tersebut, kemudian dilakukan analisis data untuk membuktikan hipotesis penelitian yang dilakukan dengan menggunakan uji normalitas dan uji perbedaan rata-rata. Uji normalitas digunakan untuk menentukan bahwa data yang telah dikumpulkan berdistribusi normal atau tidak berdistribusi normal. Uji perbedaan rata-rata digunakan menguji kemampuan perbedaan berpikir kritis matematik siswa.

Uji normalitas dengan menggunakan SPSS. Sebuah program aplikasi yang memiliki kemampuan analisis statistik cukup tinggi dan hasilnya adalah sig Kolmogorov Smirnov untuk 
kelas biasa 0.074 dan untuk kelas unggulan yakni 0.124 . Kesimpulannya sig Kolmogorov Smirnov $<0.05$ artinya data berdistribusi normal. Setelah data dinyatakan berdistribusi normal dilakukan uji perbandingan rata-rata. Hasilnya sebagai berikut bahwa nilai sig ( 2 tailed) adalah 0.000. Karena, nilai sig $\leq 0.05$ maka $\mathrm{H}_{0}$ ditolak. Dengan demikian terdapat perbedaan rata-rata kemampuan berpikir kritis matematik siswa antara kelas unggulan dengan siswa kelas biasa.

Berikut adalah faktor-faktor yang digunakan oleh peneliti untuk memperlihatkan bahwa siswa memiliki kemampuan berpikir kritis, yaitu 1) siswa tidak dapat memahami soal dengan benar, 2) siswa terburu-buru dalam mengerjakan soal, 3) siswa tidak dapat memilih strategi pemecahan masalah dengan benar dan 4) siswa mengerjaan soal dengan sistematis.

Disajikan satu soal yang akan ditunjukkan oleh peneliti untuk membanding kemampuan berpikir kkritis matematik antara kelas ungulan dan kelas biasa.

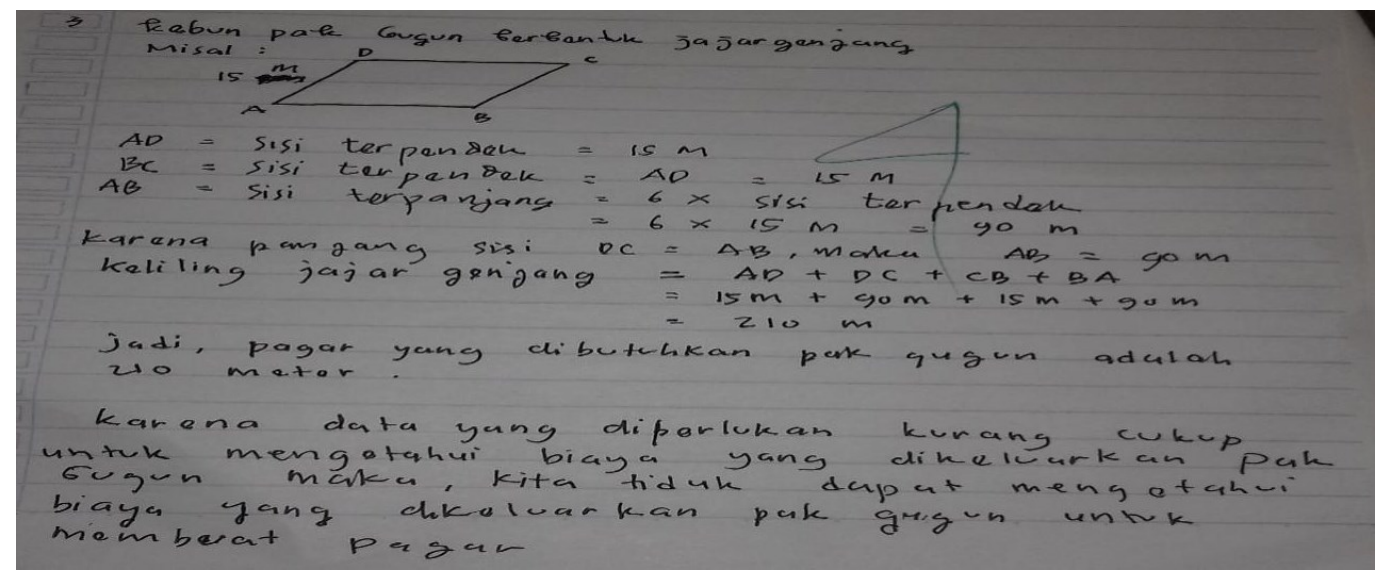

Gambar 1. Penyelesaian Soal No.3 Siswa Kelas Unggulan

Dari jawaban salah satu siswa kelas unggulan tersebut, siswa sudah menjawab dengan benar bahwa data yang diberikan kurang cukup untuk menjawab soal tersebut dan jawaban yang diberikan oleh siswa juga sudah sistematis jadi terlihat bahwa siswa bisa memahami soal dengan benar, sehingga terlihat bahwa siswa tidak terburu-buru dalam menjawab soal tersebut dan juga siswa menggunakan strategi penyelesaian dengan benar dimana siswa mencari sisi terpanjang terlebih dahulu kemudian mencari keliling jajar genjang untuk mengetahui kesimpulan dari soal tersebut. Berbeda dengan siswa biasa.

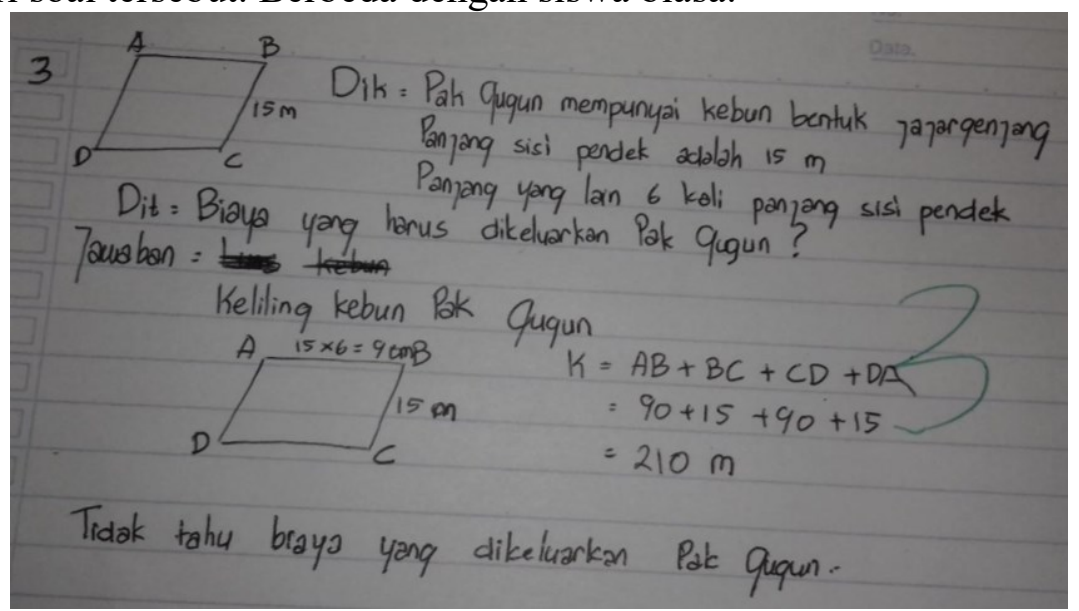

Gambar 2. Penyelesaian Soal No.3 Siswa Kelas Biasa 
Berdasarkan jawaban siswa kelas biasa di atas terlihat bahwa, siswa kurang sistematis dalam menjawab soal tersebut. Strategi yang digunakan oleh siswa tersebut sudah lengkap namun tidak sistematis dimana hal tersebut memperlihatkan bahwa siswa terburu-buru dalam menjawab soal dan kurang memahami soal dengan baik. Dari jawaban siswa kelas unggulan dan kelas biasa tersebut terlihat bahwa kemampuan kritis matematis kelas unggulan jauh lebih baik dari kelas biasa.

\section{KESIMPULAN}

Kemampuan berpikir kritis matematis siswa pada kelas unggulan lebih baik dari pada kemampuan berpikir kritis matematis kelas biasa. Strategi yang digunakan kelas unggulan dalam memecahkan masalah lebih baik dan sistematis dari pada strategi yang digunakan oleh kelas biasa, selain itu kelas biasa juga cenderung terburu-buru dibandingkan dengan kelas unggulan dalam memahami apa yang ditanyakan pada soal.

Kemampuan berpikir kritis matematik pada tingkat sekolah sangat penting untuk siswa agar terbiasa dalam menghadapi setiap permasalahan yang ada di sekitarnnya. Agar kemampuan berpikir kritis matematik siswa menjadi lebih baik maka peran guru sangat penting dalam proses mengembangkannya. Kemampuan awal siswa diperlukan untuk dapat menngembangkan potensi siswa dalam pembelajaran di sekolah

\section{DAFTAR PUSTAKA}

Hendyawan, S., Yusuf, Y., Wachar, T. Y., Ciregar, I., \& Dwiyani, W. (2017). Analisis Kemampuan Berpikir Matematis Siswa SMP Tingkat Rendah Pada Pembelajara Berbasis Masalah Dengan Green's Motivasional Strategis. AKSIOMA, 8(2).

Hidayat, W. (2011). Meningkatkan Kemampuan Berpikir Kritis dan Kreatif Matematik Siswa Melalui Pembelajaran Kooperatif Think-Talk-Write (TTW) (Doctoral dissertation, Universitas Pendidikan Indonesia).

Hidayat, W. (2012). Meningkatkan Kemampuan Berpikir Kritis dan Kreatif Matematik Siswa SMA Melalui Pembelajaran Kooperatif Think-Talk-Write (TTW). In Seminar Nasional Penelitian, Pendidikan dan Penerapan MIPA.

Ikhsan, M., \& Rizal, S. (2014). Penerapan Model Pembelajaran Berbasis Masalah untuk Meningkatkan Kemampuan Berpikir Kritis dan Disposisi Matematis Siswa. Jurnal Didaktik Matematika, 1(1).

Novtiar, C., \& Aripin, U. (2017). MENINGKATKAN KEMAMPUAN BERPIKIR KRITIS MATEMATIS DAN KEPERCAYAAN DIRI SISWA SMP MELALUI PENDEKATAN OPEN ENDED. PRISMA, 6(2).

Rasiman. (2012). Penelusuran Proses Berpikir Kritis Dalam Peyelesaian Masalah Matematika Bagi Siswa Dengan Kemampuan Matematika Tinggi. AKSIOMA, 3(2).

Ruseffendi, E. T. (2010). Dasar-Dasar Penelitian Pendidikan dan Bidang Non-Eksakta Lainnya. Bandung: Tarsito. 
Sumarmo, U., Hidayat, W., Zukarnaen, R., Hamidah, M., \& Sariningsih, R. (2012). Kemampuan dan Disposisi Berpikir Logis, Kritis, dan Kreatif Matematik (Eksperimen terhadap Siswa SMA Menggunakan Pembelajaran Berbasis Masalah dan Strategi ThinkTalk-Write). Jurnal Pengajaran MIPA, 17(1), 17-33.

Syahbana, A. (2012). Peningkatan kemampuan berpikir kritis matematis siswa smp melalui pendekatan contextual teaching and learning. EDUMATICA (Journal Pendidikan Matematika), 2(1), 45-57.

Tresnawati, T., Hidayat, W., \& Rohaeti, E. E. (2017). Kemampuan Berpikir Kritis Matematis dan Kepercayaan Diri Siswa SMA. Symmetry: Pasundan Journal of Research in Mathematics Learning and Education, 2(2), 39-45. 